Article

\title{
Spatiotemporal Changes of Antibiotic Resistance and Bacterial Communities in Drinking Water Distribution System in Wrocław, Poland
}

\author{
Agata Siedlecka *DiD, Mirela Wolf-Baca and Katarzyna Piekarska \\ Department of Environmental Protection Engineering, Faculty of Environmental Engineering, \\ Wrocław University of Science and Technology, Wyb. Wyspiańskiego 27, 50-370 Wrocław, Poland; \\ mirela.wolf-baca@pwr.edu.pl (M.W.-B.); katarzyna.piekarska@pwr.edu.pl (K.P.) \\ * Correspondence: agata.siedlecka@pwr.edu.pl; Tel.: +48-71-320-25-32
}

Received: 31 July 2020; Accepted: 15 September 2020; Published: 17 September 2020

check for updates

\begin{abstract}
Antibiotic resistance of bacteria is an emerging problem in drinking water treatment. This paper presents the comparison of antibiotic resistant bacteria (ARB) and antibiotic resistance genes (ARGs) prevalence during the summer and winter season in a full-scale drinking water distribution system (DWDS) supplied by two water treatment plants (WTPs). The effect of distance from WTP and physical-chemical water parameters on its microbial properties was also tested. Bacterial consortia dwelling in bulk tap water were additionally compared by means of denaturating gradient gel electrophoresis (DGGE). The results showed that among ARB, bacteria resistant to ceftazidime (CAZ) were the most abundant, followed by bacteria resistant to amoxicillin (AML), ciprofloxacin (CIP), and tetracycline (TE). Numerous ARGs were detected in tested tap water samples. Only CAZ resistant bacteria were more prevalent in the season of increased antibiotic consumption, and only AML resistant bacteria relative abundances increase was statistically significant with the distance from a WTP. The investigated tap water meets all legal requirements. It is therefore safe to drink according to the law. Nevertheless, because antibiotic resistance could pose a threat to consumer health, it should be further monitored in DWDSs.
\end{abstract}

Keywords: tap water; antibiotic resistant bacteria; antibiotic resistance genes; DGGE

\section{Introduction}

Antibiotic resistance (in this paper, the term antibiotics refers to all substances with antibacterial properties, produced by microorganisms, synthetically or semi-synthetically [1,2]) of bacteria has become a global problem, posing a serious threat to human health and life [3,4]. According to World Health Organization (WHO), due to antibiotic resistance, many infections have become difficult to treat, leading to longer hospital stays, higher medical costs, and even increased mortality $[5,6]$. Bacterial resistance can develop and disseminate via mutations and horizontal gene transfer (HGT) $[2,7]$. Moreover, antibiotic resistance spread can be facilitated by mobile genetic elements (MGEs), including plasmids, transposons, and integrons $[5,8,9]$. Therefore, developed or acquired resistance can be further disseminated between clinical and natural environments.

Multidrug resistant bacteria, so-called 'superbugs', can be divided in two groups, namely well-known pathogens of clinical relevance, and opportunistic pathogens of environmental origin, frequently intrinsically resistant to multiple antibiotics, and therefore posing a threat to immunocompromised patients [10]. Natural environments, particularly soil and water, have become recognized as recipients, reservoirs, and sources of antibiotic resistant bacteria (ARB) and antibiotic resistance genes (ARGs) of clinical concern [2,11,12]. Moreover, despite the presence of bacterial 
antibiotic resistance in natural environments [2,5], the over-use of antibiotics in human medicine, veterinary medicine, or as growth promoters contributes to its further anthropogenic development and dissemination [12-14]. Therefore, careful monitoring of antibiotic resistance determinants, including ARB and ARGs in the environments is of high importance [15-17].

Antibiotics, ARB, and ARGs can be introduced into aquatic ecosystems through wastewater effluents, land run-offs, or aquacultures $[8,12,13]$. The selective pressure exerted by antibiotics, diluted in waters to concentrations far below minimum inhibitory concentration (MIC), can contribute to further prevalence of resistance $[8,13]$. Furthermore, the presence of antibiotics, ARB, and ARGs in source water can be challenging for conventional, as well as advanced water treatment technologies [18]. According to many studies, biologically activated carbon [19-22] and disinfection processes [9,18,23-32] can contribute to the dissemination and enrichment of ARB and ARGs during water treatment, resulting in the presence of antibiotic resistance in finished and tap water. Moreover, residual disinfectant is suspected to contribute to bacterial community shift and resistome alteration in drinking water distribution systems (DWDSs) [26,30,33,34].

Consumer health risk assessment related to the presence of ARB in tap water needs further investigation $[7,35,36]$. Nevertheless, it has been evidenced that consumers who used drinking water contaminated with antibiotic resistant Escherichia coli in their households were more exposed to the carriage of this bacterium [37]. Moreover, human intestinal bacteria were suggested to exchange genes with swallowed bacteria passing through human digestive system [38].

ARB were detected in tap water almost 40 years ago $[39,40]$, and together with ARGs, they have been further investigated over the recent decades [7,9,18,25,26,30-32,36,37,41-60]. Knowledge on their seasonal variation [25,55], however, as well as knowledge on the effect of various treatment technologies [18] or tap water transportation via distribution system [26] on antibiotic resistance determinants in chlorinated DWDSs is still scarce and this study aims to fill this gap. To the authors' best knowledge, this is the first paper comparing results obtained in different seasons (summer and winter) on ARB, ARGs, and bacterial community structures (investigated by means of denaturating gradient gel electrophoresis (DGGE)) in a full-scale DWDS in East-Central Europe. Because antibiotic consumption in Poland is one of the highest in Europe [14,61], and Polish surface waters were reported to be contaminated by antibiotics and ARB $[14,16]$, the monitoring of antibiotic resistance determinants in the water supply network ecosystem is of importance.

This study focused on resistance migration and bacterial community shift via a distribution system. Previous preliminary research conducted on Wrocław tap water during the summer season showed presence of ARB and ARGs in DWDS [54]. Because winter is known to be the season of intensified antibiotic consumption in Europe [61], comparison of ARB and ARGs prevalence in the same points within DWDS between these seasons is justified, and can contribute to expanding knowledge on bacterial response to contamination of the environment by antibiotics. In this study, the analyses of summer samples were extended, and samples collected during the winter sampling campaign were investigated. The results of research conducted on samples collected both in the summer and winter sampling campaign were compared to fully depict the antibiotic resistance phenomenon in bulk tap water within Wrocław DWDS. Moreover, a previous study demonstrated spatial diversity of bacterial community composition in Wrocław [62]. In this paper, spatiotemporal differences of bacterial genotypes present in bulk tap water were determined by means of DGGE.

The objectives of this study were as follows: (i) to characterize ARB and ARGs occurring within Wrocław DWDS during the summer and winter season, (ii) to determine the seasonal variation and effect of treatment technologies applied by independent water treatment plants (WTPs) on antibiotic resistance prevalence in Wrocław DWDS, (iii) to determine correlations between microbiological water properties (i.e., ARB, heterotrophic plate counts (HPC), and ARGs) and distance from WTP and physical-chemical water parameters (i.e., free and total chlorine concentrations and tap water temperature), (iv) to investigate spatiotemporal changes in bacterial consortia genotypes within DWDS by means of DGGE. 


\section{Materials and Methods}

\subsection{DWDS in Wroctaw}

The water supply network in Wrocław consists of three WTPs, namely Na Grobli (NG), Mokry Dwór (MD), and Leśnica (L), and a distribution system common for WTPs NG and MD. Figure 1 presents areas supplied by each WTP, additional disinfection points providing an appropriate level of residual disinfectant [63], and sampling points.

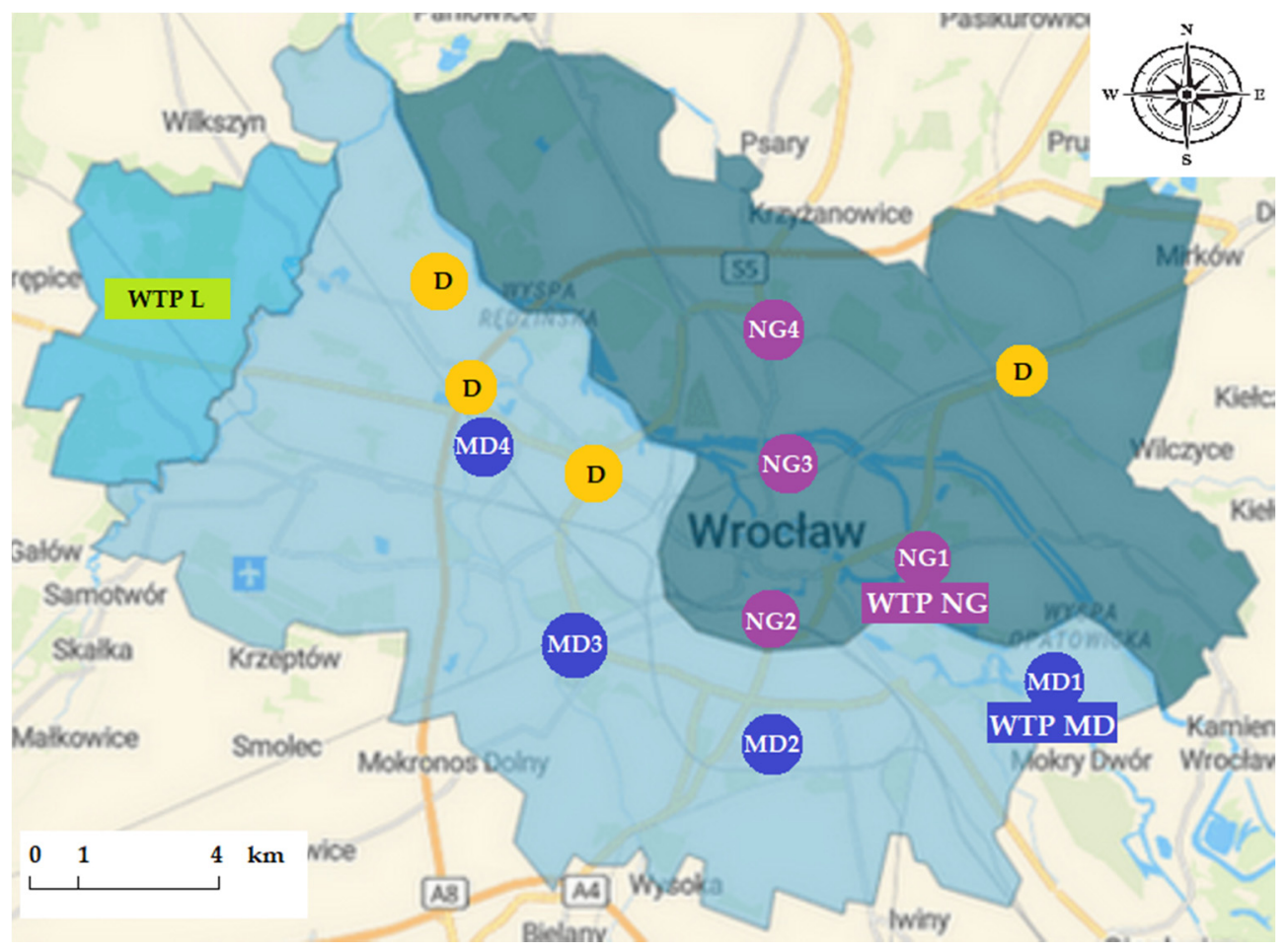

Figure 1. Sampling points numbered consecutively, areas of water supply from water treatment plants (WTPs) Na Grobli (NG), Mokry Dwór (MD), Leśnica (L) and additional disinfection points (D) in the Wrocław drinking water distribution system. Own elaboration based on data provided by the Municipal Water and Sewerage Company in Wrocław.

This study covered water samples from areas supplied by WTPs NG and MD. Because WTP L supplies drinking water only to a minor part of the city, this plant was not included in the research.

Both WTPs (NG and MD) draw source water from the Oława and Nysa Kłodzka Rivers. In WTP NG, however, ground infiltration is implemented as the first step of treatment, making water take on groundwater features. In both WTPs, chlorine and chlorine dioxide are used for disinfection purposes.

WTP NG consists of the following treatment processes: ground infiltration, aeration, filtration, ozonation, adsorption on activated carbon, $\mathrm{pH}$ correction, and disinfection. WTP MD consists of the following treatment processes: coagulation, filtration, ozonation, adsorption on activated carbon, $\mathrm{pH}$ correction, and disinfection.

This study involved collection of samples of finished water entering the distribution system from both WTPs (NG1 and MD1), as well as recipients' tap water from consecutive taps (NG2, NG3, NG4, and MD2, MD3, MD4). The location of consecutive sampling taps is in accordance with water transfer via the distribution system (Figure 1). The idea was to select sampling points at increasing distances from each WTP, to preliminary asses the differences in antibiotic resistance in tap water collected close and far away from each WTP. Wrocław DWDS includes an area of mixed streams from both investigated WTPs. Points located within this area were deliberately omitted. 


\subsection{Sample Collection}

A previous study [54] presented preliminary results of analyses of samples collected during the summer sampling campaign (July and August 2018). In this study, these samples were further investigated, and samples from the same points were collected during the winter sampling campaign (January and February 2019) in accordance with identical collection and research procedures.

All samples were collected in public buildings (except for sampling point MD2, located in a pumping station) in cooperation with the Municipal Water and Sewerage Company (MWSC), according to MWSC guidelines (i.e., tap disinfection and water flushing until temperature stabilization). Microbiological properties (total coliforms, Escherichia coli, Clostridium perfringens, and total number of bacteria after incubation at $22{ }^{\circ} \mathrm{C}$ for $72 \mathrm{~h}$ ) and physical-chemical parameters (temperature, turbidity, color, $\mathrm{pH}$, conductivity, free and total chlorine, chlorites and chlorates, nitrates, and aluminum) were kindly provided by MWSC. For the purposes of antibiotic resistance investigation, $15 \mathrm{~L}$ of tap water was collected from each sampling point twice in a season (in July and August for summer and in January and February for winter) to sterile plastic containers, supplemented with $0.1 \mathrm{~g} / \mathrm{L}$ sodium thiosulfate (Chempur, Piekary Ślaskie, Poland) to neutralize the disinfectants [34], transported to the laboratory, and immediately processed in sterile conditions.

\subsection{Relative Abundances of $A R B$ and Total Number of Bacteria}

Relative abundances of bacteria resistant to amoxicillin (AML), ciprofloxacin (CIP), ceftazidime (CAZ), and tetracycline (TE) were determined in HPC. These antibiotics were selected as representatives of antibiotic groups most commonly consumed in Poland [61], namely $\beta$-lactams, fluoroquinolones, 3rd generation cephalosporins, and tetracyclines, respectively. For this purpose, tap water was concentrated by filtration through mixed cellulose membranes of $0.2 \mu \mathrm{m}$ pore diameter (Whatman, Little Chalfont, United Kingdom) by means of a sterile filtration set (Nalgene, Rochester, NY, USA). Next, the membranes were placed on plates of R2A (BTL, Łódź, Poland) or R2A (BTL, Łódź, Poland) supplemented with antibiotic (Sigma-Aldrich, St. Louis, MO, USA), prepared in accordance with the guidelines [64,65], as presented in Table 1 .

Table 1. Agar media supplementation for enumeration of heterotrophic plate counts (HPC) and antibiotic resistant bacteria [54,55].

\begin{tabular}{ccc}
\hline Agar Medium & Antibiotic and Concentration & Purpose \\
\hline R2A & - & psychrophilic HPC \\
R2A + AML & amoxicillin $8 \mathrm{mg} / \mathrm{L}$ & $\%$ of bacteria resistant to amoxicillin \\
R2A + CIP & ciprofloxacin $2 \mathrm{mg} / \mathrm{L}$ & $\%$ of bacteria resistant to ciprofloxacin \\
R2A + CAZ & ceftazidime $8 \mathrm{mg} / \mathrm{L}$ & $\%$ of bacteria resistant to ceftazidime \\
R2A + TE & tetracycline $16 \mathrm{mg} / \mathrm{L}$ & $\%$ of bacteria resistant to tetracycline \\
\hline
\end{tabular}

The plates were incubated at $22{ }^{\circ} \mathrm{C}$ for 7 days. Afterwards, colony forming units (CFU) were counted, and relative abundances (\%) of ARB in total HPC were calculated. For quality control, the Escherichia coli ATCC 25,922 and Pseudomonas aeruginosa ATCC 27,853 strains (BioMaxima, Lublin, Poland) were inoculated on each batch of prepared plates.

\subsection{DNA Extraction}

Considering low biomass of bacteria in collected samples, up to $10 \mathrm{~L}$ of tap water from each sample was concentrated by filtration through mixed cellulose membranes of $0.2 \mu \mathrm{m}$ pore diameter (Whatman) by means of a sterile filtration set (Nalgene). DNA was extracted from membranes by means of a DNeasy PowerWater kit (QIAGEN, Hilden, Germany) in accordance with manufacturers' instructions. DNA eluates from samples collected in July and August were pooled to prepare a representative sample for the summer season [54], whereas DNA eluates from samples collected in January and February were pooled to prepare a representative sample for the winter season. As a result, each DNA 
sample was prepared from up to $20 \mathrm{~L}$ of tap water for each sampling point. A total of 16 DNA samples were obtained (8 for each summer and winter season). DNA concentration and purity were measured by means of a NanoPhotometer N60 (Implen, München, Germany).

\subsection{Detection of ARGs and Other Genes in Environmental DNA}

PCRs were conducted in Mastercycler Nexus GX2 (Eppendorf, Hamburg, Germany) to detect ARGs and other genes related to HGT or resistance mechanisms: bla $a_{\mathrm{TEM}}, b l a_{\mathrm{SHV}}, b l a_{\mathrm{CTX}-\mathrm{M}}, b l a_{\mathrm{KPC}}$, $b l a_{\mathrm{NDM}}, b l a_{\mathrm{OXA}}, b l a_{\mathrm{OXA}-48}, \operatorname{amp} \mathrm{C}, m e c \mathrm{~A}, q n r \mathrm{~A}, q n r \mathrm{~B}, q n r \mathrm{~S}, \operatorname{oqx} \mathrm{B}$, tet $\mathrm{A}$, tet $\mathrm{K}$, tet $\mathrm{L}$, tet $\mathrm{W}, \operatorname{sul\mathrm {I}}, \operatorname{sul\mathrm {II}}, \operatorname{erm} \mathrm{A}$, erm $\mathrm{B}, \operatorname{van} \mathrm{A}, m c r-1, \operatorname{mex} \mathrm{A}$, flo $\mathrm{R}, q a c \mathrm{E} \Delta 1, q a c \mathrm{H}$, tolA, int $\mathrm{I} 1, \operatorname{tnp} \mathrm{A}$ in environmental DNA samples. Moreover, $16 \mathrm{~S}$ rRNA gene was amplified in terms of DNA quality control. Detailed information regarding primer sequences, amplicon sizes, and annealing temperature is provided in Supplementary Material (Table S1). The PCR mixture consisted of: $12.5 \mu \mathrm{L}$ of 2xStartWarm HS-PCR Mix (A\&A Biotechnology, Gdynia, Poland), $1 \mu \mathrm{L}$ of each $10 \mu \mathrm{M}$ primer (Genomed, Warsaw, Poland), $2.5 \mu \mathrm{L}$ of DNA, and $8 \mu \mathrm{L}$ of water (A\&A Biotechnology, Gdynia, Poland). PCR protocols were as follows: initial denaturation at $95{ }^{\circ} \mathrm{C}$ for $5 \mathrm{~min}$, followed by 40 cycles of denaturation at $95^{\circ} \mathrm{C}$ for $15 \mathrm{~s}$, annealing at $\mathrm{T}_{\mathrm{a}}$ for $30 \mathrm{~s}$, elongation at $72{ }^{\circ} \mathrm{C}$ for $30 \mathrm{~s}$, and final elongation at $72{ }^{\circ} \mathrm{C}$ for $7 \mathrm{~min}$. In each reaction, negative and positive controls were applied. After PCR amplification, $5 \mu \mathrm{L}$ of each product was separated by electrophoresis in $2 \%$ or $3 \%$ (depending on the amplicon size) agarose gel (Sigma-Aldrich) stained with Green DNA Gel Stain (Syngen Biotech, Wrocław, Poland). The products were electrophoresed at $120 \mathrm{~V}$ for $15 \mathrm{~min}$ and at $80 \mathrm{~V}$ for $60 \mathrm{~min}$ in $1 \times$ TBE buffer, and visualized by UV (UVITEC, Cambridge, UK). The amplicon size was compared with DNA Marker pUC/Msp I (A\&A Biotechnology).

\subsection{DGGE Analysis of Community Structures}

The community structures of bacterial consortia were compared by means of DGGE. Due to low bacterial biomass in investigated samples, nested-PCR protocol was applied in Mastercycler Nexus GX2 (Eppendorf, Hamburg, Germany). Nearly full 16S rRNA gene was amplified with primer set 27F (AGAGTTTGATCMTGGCTCAG) and 1492R (TACGGYTACCTTGTTACGACTT) [66].

The PCR mixture consisted of: $4 \mu \mathrm{L}$ of 5xGold Hot Start PCR MIX LOAD (Syngen), $0.4 \mu \mathrm{L}$ of each $10 \mu \mathrm{M}$ primer (Genomed), $2 \mu \mathrm{L}$ of DNA, and $13.2 \mu \mathrm{L}$ of water (A\&A Biotechnology). The touchdown PCR protocol was as follows: initial denaturation at $95{ }^{\circ} \mathrm{C}$ for $15 \mathrm{~min}$, followed by 25 cycles of denaturation at $95{ }^{\circ} \mathrm{C}$ for $15 \mathrm{~s}$, annealing at $55-50{ }^{\circ} \mathrm{C}$ for $30 \mathrm{~s}$, elongation at $72{ }^{\circ} \mathrm{C}$ for $60 \mathrm{~s}$, and final elongation at $72{ }^{\circ} \mathrm{C}$ for $7 \mathrm{~min}$. Negative control was applied to confirm lack of external contamination in reaction. Positive control was prepared of genomic DNA of two strains from laboratory collection, i.e., Escherichia coli and Pseudomonas fluorescens.

After PCR amplification, $5 \mu \mathrm{L}$ of each product was separated by electrophoresis in $1 \%$ agarose gel (Sigma-Aldrich) stained with Green DNA Gel Stain (Syngen). The products were electrophoresed at $120 \mathrm{~V}$ for $15 \mathrm{~min}$ and at $80 \mathrm{~V}$ for $60 \mathrm{~min}$ in $1 \times$ TBE buffer and visualized by UV (UVITEC). The amplicon size was compared with DNA Marker 3 (A\&A Biotechnology). Samples NG1S, MD1S, MD2S, MD3S, NG1W, MD1W (where 'S' refers to summer and 'W' refers to winter sampling campaigns, respectively) gave only weak bands, hampering their inclusion in the DGGE analysis.

Only samples NG2S, NG3S, NG4S, MD4S, NG2W, NG3W, NG4W, MD2W, MD3W, MD4W were included in further steps. The post-reaction mixture was used as a DNA template for amplification of an approximately 200-bp 16S rRNA gene fragment, corresponding to region V3, with primer set 338F-GCclamp (5'-GACTCCTACGGGAGGCAGCAG-3' with a GC clamp attached) and 518R (5'-ATTACCGCGGCTGCTGG-3') [34,67].

The PCR mixture consisted of: $4 \mu \mathrm{L}$ of 5xGold Hot Start PCR MIX (Syngen), $0.4 \mu \mathrm{L}$ of each $10 \mu \mathrm{M}$ primer (Genomed), $0.5 \mu \mathrm{L}$ of DNA, and $14.7 \mu \mathrm{L}$ of water (A\&A Biotechnology). Touchdown PCR protocol was as follows: initial denaturation at $95^{\circ} \mathrm{C}$ for $15 \mathrm{~min}$, followed by 30 cycles of denaturation at $95{ }^{\circ} \mathrm{C}$ for $20 \mathrm{~s}$, annealing at $62-53{ }^{\circ} \mathrm{C}$ for $1 \mathrm{~min}$, elongation at $72{ }^{\circ} \mathrm{C}$ for $2 \mathrm{~min}$, and final elongation at $72{ }^{\circ} \mathrm{C}$ for $7 \mathrm{~min}$. The products were purified with Clean-up Concentrator (A\&A Biotechnology,) in 
accordance with manufacturers' instructions. The DNA concentration of the nested-PCR products was determined by NanoPhotometer N60 (Implen). Approximately $270 \mathrm{ng}$ of DNA were loaded onto a vertical polyacrylamide gel ( $8 \% \mathrm{w} / \mathrm{v})$ with a denaturing gradient ranging from $30 \%$ to $60 \%$. The products were electrophoresed at $120 \mathrm{~V}$ for $15 \mathrm{~min}$ and at $70 \mathrm{~V}$ for $16 \mathrm{~h}$ in $1 \times \mathrm{TAE}$ buffer on Denaturing Gradient Gel Electrophoresis Systems DGGEK-2001 (CBS Scientific, San Diego, CA, USA). The gel was stained for 15 min with ethidium bromide (Sigma Aldrich), then washed with 1xTAE buffer for $20 \mathrm{~min}$, and visualized by UV and photographed (UVITEC).

The DGGE profiles were analyzed with CLIQS software (TotalLab, Newcastle Upon Tyne, UK) to get similarity matrices-based on the presence or absence of the bands. The dendrogram was created by the unweighted pair group method using arithmetic mean algorithm (UPGMA). The synthetic line created based on the investigated lines was used as a reference line for dendrogram construction.

\subsection{Statistical Analyses}

This study investigated the effect of the season (summer or winter), as well as water treatment technology (WTP NG or MD) on ARB, HPC, and ARGs, free and total chlorine concentrations and tap water temperature. It also tested the correlations of the aforementioned factors and distance from each WTP. Normality and homoscedasticity of data were verified using Shapiro-Wilk and Levene's tests, respectively. If normality was confirmed, a Student's $t$-test was used; otherwise a Mann-Whitney $U$-test was conducted to detect differences. Correlations were assessed using Pearson or Spearman correlation analyses, depending on the normality of the data. The significance level across the study was set at $p<0.05$. All statistical analyses were done in Microsoft Excel software (Microsoft Office 365 ProPlus, Redmond, WA, USA).

\section{Results}

\subsection{Tap Water Parameters}

Tap water samples were of good quality in terms of microbiological properties and physical-chemical parameters (Table S2). No total coliforms, Escherichia coli, Clostridium perfringens were found in any sample, and the total number of bacteria was lower than established in the guidelines [68], suggesting sufficient water disinfection in WTPs and within the distribution system. All samples had acceptable taste and smell. Other physical-chemical tap water parameters are presented in Table 2.

Table 2. Ranges of physical-chemical parameters of tap water samples collected in both sampling campaigns, provided by the Municipal Water and Sewerage Company in Wrocław.

\begin{tabular}{ccc}
\hline Physical-Chemical Parameter & Range & Medium \\
\hline temperature $\left({ }^{\circ} \mathrm{C}\right)$ & $2.1-22.5$ & 14.7 \\
turbidity $(\mathrm{NTU})$ & $<0.5$ & - \\
color $(\mathrm{mg} / \mathrm{L} \mathrm{Pt})$ & $<2$ & - \\
$\mathrm{pH}$ & $7.50-7.85$ & 7.64 \\
conductivity $(\mu \mathrm{S} / \mathrm{cm})$ & $409-735$ & 602 \\
free $\mathrm{Cl}_{2}(\mathrm{mg} / \mathrm{L})$ & $0.00-0.31$ & 0.10 \\
total $\mathrm{Cl}_{2}(\mathrm{mg} / \mathrm{L})$ & $0.10-0.49$ & 0.27 \\
chlorites and chlorates $(\mathrm{mg} / \mathrm{L})$ & $0.05-0.26$ & 0.16 \\
nitrates $(\mathrm{mg} / \mathrm{L})$ & $1.70-27.00$ & 7.45 \\
aluminum $(\mu \mathrm{g} / \mathrm{L})$ & $10-25$ & 16.85 \\
\hline
\end{tabular}

\subsection{Relative Abundances of $A R B$ and Total Number of Bacteria}

The mean values of relative abundances (\%) of ARB in total HPC in each sampling point in the summer and winter season are presented in Figure 2. The highest relative abundances were observed in order CAZ-, AML-, CIP-, and TE resistance, highlighting the prevalence of CAZ resistant bacteria in Wrocław DWDS. 


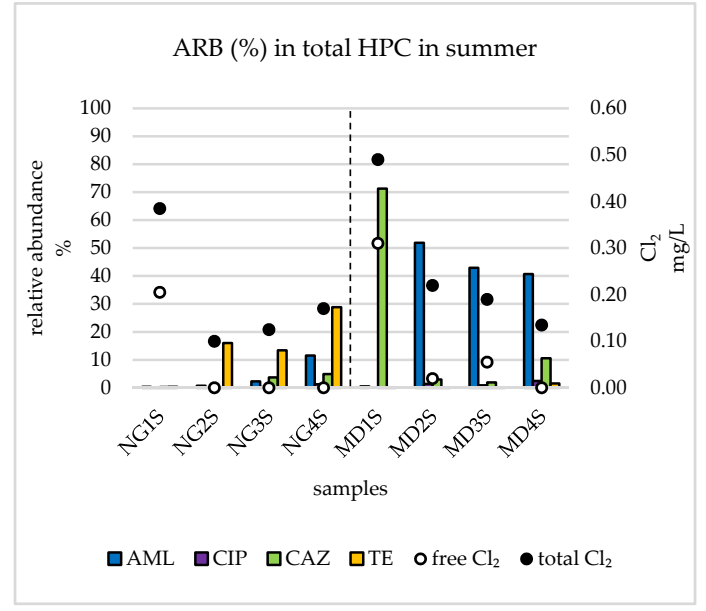

(a)

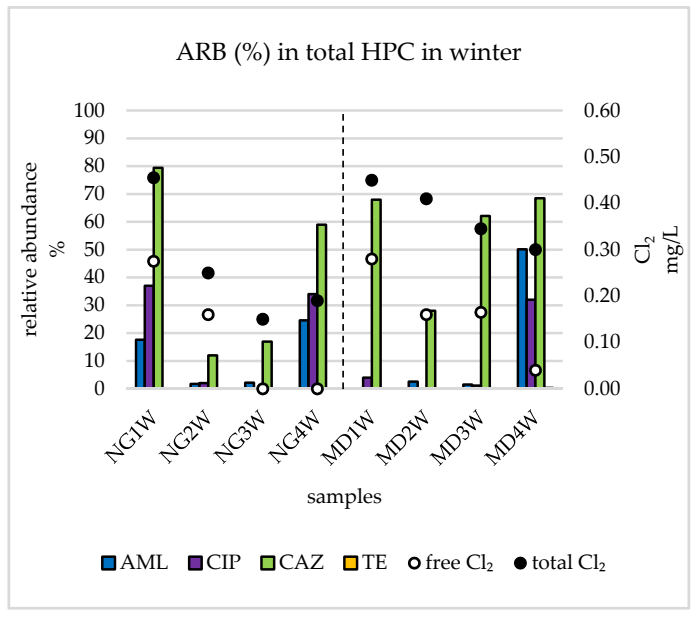

(b)

Figure 2. Comparison of relative abundances of antibiotic resistant bacteria in the summer [54] (a) and winter (b) season in consecutive points. NG refers to water treatment plant Na Grobli, MD refers to water treatment plant Mokry Dwór, numbers refer to sampling points, $\mathrm{S}$ refers to summer, and $\mathrm{W}$ refers to winter. $\mathrm{Cl}_{2}$ : chlorine, AML: amoxicillin resistant bacteria, $\mathrm{CIP}$ : ciprofloxacin resistant bacteria, CAZ: ceftazidime resistant bacteria, TE: tetracycline resistant bacteria.

Relative abundances of CAZ- and TE resistant bacteria were statistically significantly season-dependent, with higher prevalence in winter and summer, respectively. The results of Spearman correlations demonstrated that relative abundances of AML resistant bacteria were positively correlated with distance from WTPs $($ rho $=0.64)$. Relative abundances of CAZ resistant bacteria were positively correlated with both free and total $\mathrm{Cl}_{2}$ ( $\mathrm{rho}=0.50$ and 0.66 , respectively), and negatively correlated with tap water temperature (rho $=-0.56)$. In contrast, relative abundances of TE resistant bacteria were negatively correlated with total $\mathrm{Cl}_{2}(\mathrm{rho}=-0.51)$, and positively correlated with tap water temperature $($ rho $=0.61)$.

Total number of bacteria determined in terms of HPC after 7 days of incubation did not exceed acceptable values [68]. HPC demonstrated statistically significant seasonal variability in a range of $1-31 \mathrm{CFU} / \mathrm{mL}$ in summer and $1-2 \mathrm{CFU} / \mathrm{mL}$ in winter. Moreover, HPC correlated negatively with free and total chlorine ( $r h o=-0.60$ and -0.71 , respectively), and positively with tap water temperature $($ rho $=0.58)$. Although not statistically significant, HPC rose with the distance from WTP during summer, and remained at the same level throughout DWDS during winter.

No effect of water treatment technologies on tap water microbiological properties was observed, and other correlations, except the ones listed above, were statistically insignificant (Table S3).

\subsection{Detection of ARGs and Other Genes in Environmental DNA}

The PCR results of both sampling campaigns are presented in Table 3. 
Table 3. Results of PCRs in the summer [54] and winter season. NG refers to water treatment plant Na Grobli, MD refers to water treatment plant Mokry Dwór, numbers refer to sampling points, $\mathrm{S}$ refers to summer, and $\mathrm{W}$ refers to winter.

\begin{tabular}{|c|c|c|c|c|c|c|c|c|c|c|c|c|c|c|c|c|c|c|c|}
\hline \multirow{2}{*}{ ভّ̃̃ } & \multirow{2}{*}{ 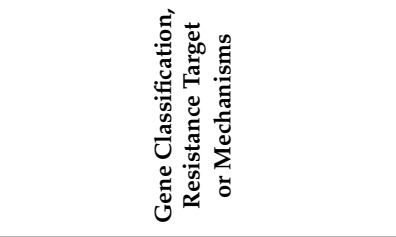 } & \multicolumn{9}{|c|}{ Summer } & \multicolumn{7}{|c|}{ Winter } & \multirow{2}{*}{ 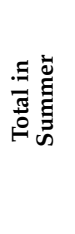 } & \multirow{2}{*}{ 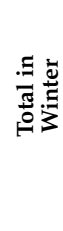 } \\
\hline & & $\begin{array}{l}0 \\
0 \\
z\end{array}$ & त్ & 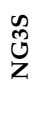 & $\begin{array}{l}\text { 号 } \\
\text { Z }\end{array}$ & $\stackrel{n}{i}$ & $\stackrel{\tilde{N}}{\hat{\Sigma}}$ & $\stackrel{\infty}{\tilde{N}}$ & $\stackrel{n}{\Sigma}$ & \begin{tabular}{l}
3 \\
\multirow{3}{Z}{} \\
$z$
\end{tabular} & $\begin{array}{l}\text { đે } \\
\text { Z }\end{array}$ & $\begin{array}{l}3 \\
0 \\
\mathbf{3}\end{array}$ & $\begin{array}{l}3 \\
\text { J } \\
Z\end{array}$ & $\frac{3}{\dot{2}}$ & 吝 & $\stackrel{3}{\stackrel{3}{n}}$ & 京 & & \\
\hline$b l a_{\mathrm{TEM}}$ & \multirow{8}{*}{$\beta$-lactams } & - & - & - & - & + & + & + & + & - & - & - & - & + & - & - & - & 4 & 1 \\
\hline$b^{b} a_{\mathrm{SHV}}$ & & - & - & - & - & - & - & - & - & - & - & - & - & - & - & - & - & 0 & 0 \\
\hline$b l a_{\mathrm{CTX}-\mathrm{M}}$ & & - & - & - & - & - & - & - & - & - & - & - & - & - & - & - & - & 0 & 0 \\
\hline$b l a_{\mathrm{KPC}}$ & & - & - & - & - & - & - & - & - & - & - & - & - & - & - & - & - & 0 & 0 \\
\hline$b l a_{\mathrm{NDM}}$ & & + & - & - & - & - & - & + & - & - & - & - & - & - & - & - & + & 2 & 1 \\
\hline$b^{b l a} \mathrm{OXA}$ & & - & - & - & - & - & - & - & - & - & - & - & - & - & - & - & - & 0 & 0 \\
\hline$b l a_{\mathrm{OXA}-48}$ & & - & - & - & - & - & - & - & - & - & - & - & - & - & - & - & - & 0 & 0 \\
\hline ampC & & - & - & - & - & + & + & - & + & - & - & - & - & - & - & - & - & 3 & 0 \\
\hline mecA & methicillin & - & - & - & - & - & - & - & - & - & - & - & - & - & - & - & - & 0 & 0 \\
\hline$q n r \mathrm{~A}$ & \multirow{4}{*}{ (fluoro)quinolones } & - & - & - & - & - & - & - & - & - & - & - & - & - & - & - & - & 0 & 0 \\
\hline$q n r \mathrm{~B}$ & & - & - & + & - & - & - & - & - & - & - & - & - & - & - & - & - & 1 & 0 \\
\hline qurs & & + & - & + & - & - & - & - & - & - & - & - & - & - & - & - & - & 2 & 0 \\
\hline oq $x \mathrm{~B}$ & & - & - & - & - & - & - & - & - & - & - & - & - & - & + & - & - & 0 & 1 \\
\hline tet $\mathrm{A}$ & \multirow{4}{*}{ tetracyclines } & - & - & + & - & - & - & - & + & - & - & + & + & - & - & - & - & 2 & 2 \\
\hline tet $\mathrm{K}$ & & - & - & - & - & - & - & - & - & - & + & - & - & - & - & - & - & 0 & 1 \\
\hline tet $\mathrm{L}$ & & - & - & - & - & - & - & - & - & - & - & - & - & - & - & - & - & 0 & 0 \\
\hline tet $\mathrm{W}$ & & - & - & - & - & - & - & - & - & - & + & - & - & - & + & + & - & 0 & 3 \\
\hline sulI & \multirow{2}{*}{ sulphonamides } & - & + & + & + & - & - & - & + & - & + & - & + & - & - & + & + & 4 & 4 \\
\hline sulII & & - & + & - & - & - & - & - & - & - & - & - & - & - & - & - & - & 1 & 0 \\
\hline erm $\mathrm{A}$ & \multirow[b]{2}{*}{ erythromycins } & - & - & - & - & - & - & - & - & - & - & - & - & - & - & - & - & 0 & 0 \\
\hline ermB & & - & - & - & + & - & + & - & - & + & + & + & + & + & + & + & + & 2 & 8 \\
\hline $\operatorname{van} \mathrm{A}$ & vancomycin & - & - & - & - & - & - & - & - & - & - & - & - & - & - & - & - & 0 & 0 \\
\hline$m c r-1$ & colistin & - & - & - & - & - & - & - & - & - & - & - & - & - & - & - & - & 0 & 0 \\
\hline $\operatorname{mex} \mathrm{A}$ & efflux & - & - & - & - & - & - & - & - & - & - & - & - & - & - & - & - & 0 & 0 \\
\hline$f l o \mathrm{R}$ & florfenicol & - & - & - & - & - & - & - & - & - & - & - & - & - & - & - & - & 0 & 0 \\
\hline \multirow{2}{*}{$\begin{array}{c}q a c \mathrm{E} \Delta 1 \\
q a c \mathrm{H}\end{array}$} & \multirow{2}{*}{ quaternary ammonium compounds } & - & - & + & + & - & + & - & - & - & + & + & + & + & + & - & - & 3 & 5 \\
\hline & & + & - & + & - & + & + & + & - & - & - & - & + & + & + & - & + & 5 & 4 \\
\hline tolA & transmembrane activity & - & - & - & - & + & - & - & - & - & - & - & - & - & - & - & - & 1 & 0 \\
\hline intI1 & class 1 integron & + & + & + & + & + & + & + & + & + & + & + & + & + & + & + & + & 8 & 8 \\
\hline \multirow[t]{2}{*}{$\operatorname{tnp\mathrm {A}}$} & transposon & - & + & + & + & + & + & + & - & - & - & - & - & - & - & - & - & 6 & 0 \\
\hline & total & 4 & 4 & 8 & 5 & 6 & 7 & 5 & 5 & 2 & 6 & 4 & 6 & 5 & 6 & 4 & 5 & 44 & 38 \\
\hline
\end{tabular}


The most abundant genes included: bla $\mathrm{TEM}_{1}$, tet $\mathrm{A}, \operatorname{sul\mathrm {I}}, \operatorname{erm} \mathrm{B}$, qacE $\Delta 1$, qac $\mathrm{H}$, intI1, tnp $\mathrm{A}$. Interestingly, bla $a_{\mathrm{NDM}}$ gene, producing New-Delhi metallo- $\beta$-lactamase [69], was detected in three samples. No spatiotemporal differences or correlation with tap water parameters were found in total ARGs prevalence.

\subsection{DGGE Analysis of the Community Structures}

Spatiotemporal changes in bacterial communities dwelling in Wrocław DWDS were also investigated by means of DGGE. The purpose was to compare the community structure, not to perform phylogenetic analyses. The results are presented as an UPGMA dendrogram in Figure 3.

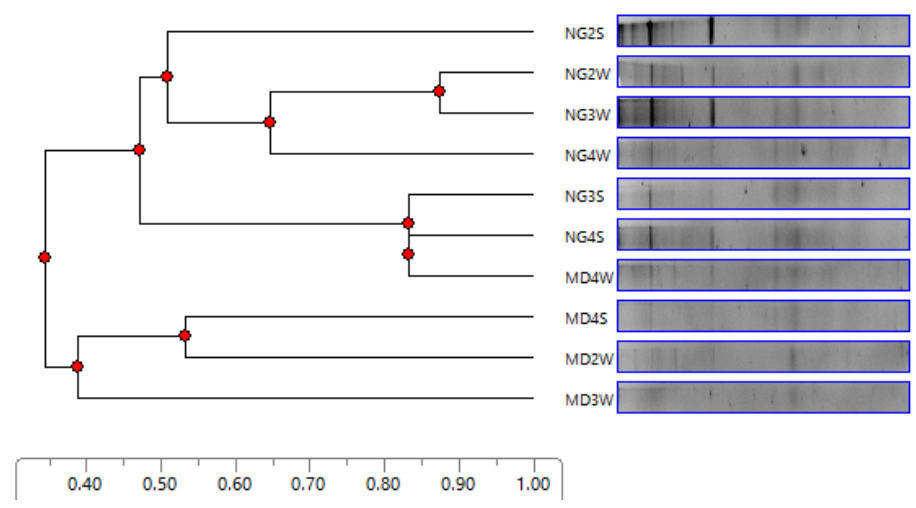

Figure 3. Dendrogram of denaturating gradient gel electrophoresis (DGGE) profiles. NG refers to water treatment plant $\mathrm{Na}$ Grobli, MD refers to water treatment plant Mokry Dwór, numbers refer to sampling points, $\mathrm{S}$ refers to summer, and $\mathrm{W}$ refers to winter.

Samples collected from WTP NG and WTP MD were generally separated from each other, excluding sample MD4W which formed a cluster with samples NG3S and NG4S. No clear seasonal clustering was observed. No similarities were also observed among samples collected from the same sampling points in summer and winter. Nevertheless, it is worth emphasizing that all samples present a mutual similarity higher than $34 \%$.

\section{Discussion}

The occurrence of ARB and ARGs in tap water has been reported worldwide, as well as in DWDS in Wrocław [7,9,18,25,26,30-32,36,37,39,40,42,43,45-60]. To the authors' best knowledge, however, this is the first study characterizing spatiotemporal changes in ARB, ARGs, and bacterial communities in bulk water samples collected from a full-scale DWDS in East-Central Europe.

Many studies to date have aimed to detect ARB in drinking water [7,30,32,36,37,39-50,52-60], and several of them failed to isolate resistant bacteria from tap water samples [41,44]. Nevertheless, antibiotic resistant Staphylococci, Enterobacteriaceae, Pseudomonas, Sphingomonadaceae, and Acinetobacter were found in tap water in Europe [42,43,45,49,50,58-60], and antibiotic resistant Escherichia coli in Asia [36,56,57], for example. Antibiotic resistant bacteria were examined over 10 years ago by $\mathrm{Xi}$ et al. [32], who found bacteria resistant to AML, CIP, and TE in ranges of 3.02-15.22\%, 0.18-13.14\%, and $0.04-3.78 \%$, respectively, in Michigan and Ohio, USA. The relative abundances determined in the present paper are considerably higher for all these ARB. These findings indicate an unflagging global problem of antibiotic resistance in DWDSs, and the need for further research in the scope. Unfortunately, no CAZ resistant bacteria, reaching the highest relative abundances in Wrocław DWDS, were examined in Michigan and Ohio [32].

Among genes investigated in this study, bla $\mathrm{TEM}_{1}, \operatorname{amp} \mathrm{C}, q n r \mathrm{~A}, q n r \mathrm{~S}, \operatorname{oq} x \mathrm{~B}$, tet $\mathrm{A}$, tet $\mathrm{W}, \operatorname{sulI}$, sulII, erm $\mathrm{A}$, $\operatorname{erm} \mathrm{B}, \operatorname{van} \mathrm{A}$, and floR were found in tap water in Tianjin, Nanjing, and Guangzhou, China [25,30,31], and $b l a_{\mathrm{TEM}}, b l a_{\mathrm{SHV}}, \operatorname{ampC}$, tetA, sulI, sulII, vanA, and intI1 genes were found in tap water in the USA and 
Europe $[32,51,52,60]$. Various other ARGs were detected in tap water in Hangzhou, China [18], and in a worldwide study [9], confirming the prevalence of ARGs in DWDSs. Previous studies conducted in China proposed sulI, sulII, floR, and $\mathrm{cmlA}$ genes as possible indicators of contamination and fate of ARGs in DWDSs [31]. In the present study, only sulI was found repeatedly in both seasons, whereas sulII was detected only in one summer sample, and floR remained undetectable. Therefore, ARG markers other than in Asia probably need to be established in East-Central Europe, although more research is needed to confirm these findings. ARGs occurrence in the water supply network is primarily influenced by source water, and other resistomes may be found in other DWDS in the region.

Frequent ARGs detection in Chinese DWDSs could be the effect of selective pressure of residual antibiotics [2,8]. Tap water in China has been reported to be contaminated by antibiotics [70-72]. In contrast, it is believed that antibiotic concentrations in tap water in Poland are below the limit of detection [14,73]. On the other hand, disinfection by-products can also induce bacterial antibiotic resistance [74], hence ARGs may be found in antibiotic-free DWDSs. Without the identification of antibiotics in Wrocław tap water, however, this statement can only be considered presumptive.

Among genes most frequently detected in this study, sulI, qacE $\Delta 1$, and int $\mathrm{I} 1$ genes were found in biofilms occurring in the WTP in Cluj, Romania [75]. Genes qac and sul could be found in class 1 integrons [76], and gene erm $\mathrm{B}$ - on transposons [77]. The presence of these genes on MGEs could partially explain the high frequency of their detection in Wrocław DWDS. Moreover, integrons and transpososns genes, namely intI 1 and $\operatorname{tnp} \mathrm{A}$, were frequently found in this study in both seasons and in summer, respectively. Their presence is suggested to potentially facilitate the HGT phenomenon in the distribution system, enabling further prevalence of resistance in tap water bacteria $[18,30,75,76]$.

The presence of several ARGs in finished water of both WTPs in both seasons could be partially explained by the application of activated carbon treatment in these plants. Biologically activated carbon filters have been evidenced to potentially enrich resistomes in treated water [18,19,22].

The discrepancies between the obtained ARB and ARGs results can be associated with the phenomenon of extracellular DNA release. It has been proven that some free DNA can be present in water environments $[25,78,79]$, and it is possible that despite the presence of several ARGs in environmental DNA samples, bacteria were not able to transform and use these free DNA molecules. Nevertheless, these genes may still be available for other, more competent bacteria, and therefore pose a threat of resistance dissemination $[5,80]$. The most probable reason, however, is that only a minor part of bacteria was able to grow on R2A medium (being viable and culturable-therefore, many ARB, probably possessing ARGs, were present in a sample, but not captured by means of the culture-dependent method. The detected genes might originate from extracellular DNA or dead bacteria alike. On the other hand, antibiotic resistance can be conferred by many ARGs [9,18], and some of them might have been omitted in this study, because only representative genes were selected for PCR detection. For example, more ARGs were found in the study of Shi et al. [30] with the application of the metagenomics approach than by means of PCR detection, demonstrating a limitation of the latter method. Resistance phenotype-genotype discrepancies of environmental bacteria have been reported in the literature $[30,81]$.

It remains unclear whether intensified consumption of antibiotics during the winter season in Europe [61] can be depicted in ARB relative abundances in DWDSs. Only CAZ resistant bacteria showed statistically significantly higher prevalence in winter, whereas TE resistant bacteria-in summer. Contrary to the results of Hao et al. [25], no seasonal resistome difference was observed in this study. Moreover, no effect of treatment technologies applied by independent WTPs on ARB, HPC, or ARGs was determined, suggesting a major effect of source water or chlorination on microbiological properties of tap water. The same observations were made in previous studies [82-84].

The statistically significant correlations found in this study can shed new light on the current state of knowledge regarding ARB within the DWDS ecosystem. In this study, only relative abundances of AML resistant bacteria correlated positively with distance from WTP, suggesting that among bacteria 
able to regrow in DWDS, AML resistant bacteria found favorable conditions and proliferated, probably benefiting over other culturable bacteria.

Nevertheless, although not statistically significant, regrowth of ARB is observed in Wrocław DWDS. No correlation between HPC and distance from WTP was found, suggesting that the residual disinfectant [63] or other factors, for example the availability of nutrients [83], play a major role in bacterial contamination of bulk tap water. Knowledge regarding resistome changes via drinking water distribution system is still scarce. The results of the present paper and previous study conducted in Nanjin, China [26], found no clear correlation between ARGs and distance from WTP.

Previous studies suggested that co-resistance against antibiotics and disinfectants can exist in tap water strains [46,85]. For example, Khan et al. [46] found weak but significant correlations between tolerance to chlorine and MIC against amoxicillin, tetracycline, and sulfamethoxazole, whereas no such correlation was found in the case of ciprofloxacin. In the present paper, no correlations were found between free and total chlorine concentrations and relative abundances of AML or CIP resistant bacteria. Nevertheless, AML resistant bacteria were frequently detected in this study, suggesting the ability of these bacteria to survive chlorine disinfection. Interestingly, positive correlations were found between free and total chlorine concentrations and relative abundances of CAZ resistant bacteria, but further research is needed to elucidate whether the co- or cross-resistance against CAZ and chlorine indeed exists in this DWDS. Furthermore, relative abundances of TE resistant bacteria were negatively correlated with total chlorine concentrations (no correlation with free chlorine concentration was found), contrary to the results of Khan et al. [46]. Unfortunately, no sulfonamide resistant bacteria were investigated in the present paper. Sulfonamide resistance genes were, however, frequently found in Wrocław DWDS (Table 3). In the present study, HPC proved to be significantly negatively correlated with free and total chlorine, and positively correlated with tap water temperature, which is in accordance with literature reports $[82,83,86,87]$.

Despite no significant dissimilarity in HPC between two investigated WTPs, DGGE profiles of total bacterial consortia seem to form clusters regarding the WTPs. In contrast, in spite of significant dissimilarity found in HPC between two seasons, no such trend is observed in DGGE dendrogram. This discrepancy could be partially explained by the fact that HPC concerns only viable and culturable bacteria, whereas DGGE patterns include total bacterial genotypes [67]. Vaz-Moreira et al. [34] claimed that alternations in bacterial community imposed by water treatment were more evident in culturable bacteria than in DGGE profiles. Perrin et al. [84] argued that only $1.8 \%$ of bacterial diversity was recovered through cultivation when compared with high-throughput sequencing of 16S rRNA gene amplicons. The DGGE results suggest that community structure genotypes may differ between areas supplied by two WTPs included in this study, but the viability of the culturable part of microflora remains influenced by seasonal changes, e.g., tap water temperature. In contrast, DGGE results presented by McCoy et al. [33] demonstrated seasonal differences among samples collected in winter, spring, summer, and autumn in DWDS in Pittsburgh, USA. Moreover, samples collected in consecutive months were clustered close to each other [33]. McCoy et al. [33] assumed that bacterial consortia were influenced by changes in hypochlorite dosage over the year. Due to no difference in chlorine concentrations between the seasons in Wrocław, it could not be mirrored in DGGE results.

It is worth emphasizing that fluctuations in relative abundances of ARB and occurrence of individual ARGs detected in this study can originate from accidental detachment of biofilm present on pipe walls, and genetic exchanges between the biofilm and planktonic bacteria $[18,41,62,75,88,89]$. Nevertheless, this study demonstrates the prevalence of ARB and ARGs, as well as changes in bacterial community structure in bulk tap water within DWDS in Wrocław, Poland, during the summer and winter season. Because antibiotic resistance has become a global health problem, presence of resistance determinants in tap water samples should not be neglected, and requires further attention. It is recommended to consider detection of ARB and ARGs in the scope of routine tap water monitoring. 


\section{Conclusions}

Wrocław bulk tap water is not free from ARB or ARGs. It is not surprising, given the fact of well-known antibiotic resistance dissemination in natural and anthropogenic environments. Because antibiotic resistance determinants can pose a threat to human health, however, this issue requires further monitoring. In this study, CAZ resistant bacteria proved to be the most prevalent in DWDS. Various genes were detected in finished water and recipients' tap water samples, including ARGs and MGEs genes, suggesting potential for HGT occurrence in the distribution system. The impact of intensified antibiotic consumption during the winter season on ARB or ARGs prevalence in the tap water ecosystem requires further examination. Only CAZ resistant bacteria proved to be more prevalent in winter, and TE resistant bacteria in summer. This means that seasonal variability of overall antibiotic resistance in DWDS could be ambiguous, although more research is needed to elucidate the issue. No effect of treatment technologies applied by two WTPs on either ARB or ARGs was found, suggesting that the source water or disinfection processes play a major role in the shaping of antibiotic resistance in DWDSs. Statistically significant regrowth via distribution system was found only for AML resistant bacteria, whereas other ARB and ARGs abundances fluctuated across the sampling sites. Interestingly, relative abundances of CAZ resistant bacteria were positively correlated with free and total chlorine. The genotype fingerprints of bacterial consortia clustered dependently on WTP rather than season or sampling point, suggesting that the community structure of non-culturable bacteria is shaped by treatment technologies, whereas culturable microflora depends more on tap water temperature or residual disinfectant. Tap water in Wrocław DWDS is generally of good microbial properties and physical-chemical parameters. No culturable pathogens were found, and overall bacterial contamination is definitely below the acceptable level specified in the guidelines. Appropriate free and total chlorine dosages provide safety for tap water consumers. Nevertheless, further ARB and ARGs monitoring in tap water is advised.

Supplementary Materials: The following are available online at http:/www.mdpi.com/2073-4441/12/9/2601/s1, Table S1: Annealing temperatures, amplicon sizes, and primer sequences used in PCRs, Table S2: Results of microbiological and physical-chemical parameters of tap water samples collected in the study, Table S3: Results of Spearman and Pearson correlations.

Author Contributions: Conceptualization, A.S.; methodology, A.S., and M.W.-B.; software, A.S.; validation, A.S. and M.W.-B.; formal analysis, A.S., M.W.-B. and K.P.; investigation, A.S.; resources, A.S. and K.P.; data curation, A.S.; writing—original draft preparation, A.S.; writing—review and editing, M.W.-B. and K.P.; supervision, K.P.; project administration, K.P.; funding acquisition, A.S., K.P. All authors have read and agreed to the published version of the manuscript.

Funding: This research received no external funding.

Acknowledgments: The authors thank the Municipal Water and Sewerage Company in Wrocław for the help in sample collection and providing data of tap water supply network and physical-chemical tap water parameters.

Conflicts of Interest: The authors declare no conflict of interest.

\section{References}

1. Diwan, V.; Hanna, N.; Purohit, M.; Chandran, S.; Riggi, E.; Parashar, V.; Tamhankar, A.J.; Lundborg, C.S. Seasonal variations in water-quality, antibiotic residues, resistant bacteria and antibiotic resistance genes of Escherichia coli isolates from water and sediments of the Kshipra River in Central India. Int. J. Environ. Res. Public Health 2018, 15, 1281. [CrossRef] [PubMed]

2. Martinez, J.L. The role of natural environments in the evolution of resistance traits in pathogenic bacteria. Proc. R. Soc. B Biol. Sci. 2009, 276, 2521-2530. [CrossRef] [PubMed]

3. Graham, D.W.; Giesen, M.J.; Bunce, J.T. Strategic approach for prioritising local and regional sanitation interventions for reducing global antibiotic resistance. Water 2018, 11, 27. [CrossRef]

4. Ng, C.; Gin, K.Y.H. Monitoring antimicrobial resistance dissemination in aquatic systems. Water 2019, $11,71$. [CrossRef] 
5. Hong, P.Y.; Julian, T.R.; Pype, M.L.; Jiang, S.C.; Nelson, K.L.; Graham, D.; Pruden, A.; Manaia, C.M. Reusing treated wastewater: Consideration of the safety aspects associated with antibiotic-resistant bacteria and antibiotic resistance genes. Water 2018, 10, 244. [CrossRef]

6. WHO. Antibiotic Resistance. Available online: https://www.who.int/news-room/fact-sheets/detail/antibioticresistance (accessed on 1 July 2020).

7. Vaz-Moreira, I.; Nunes, O.C.; Manaia, C.M. Bacterial diversity and antibiotic resistance in water habitats: Searching the links with the human microbiome. FEMS Microbiol. Rev. 2014, 38, 761-778. [CrossRef]

8. Baquero, F.; Martínez, J.-L.; Cantón, R. Antibiotics and antibiotic resistance in water environments. Curr. Opin. Biotechnol. 2008, 19, 260-265. [CrossRef]

9. Ma, L.; Li, B.; Jiang, X.T.; Wang, Y.L.; Xia, Y.; Li, A.D.; Zhang, T. Catalogue of antibiotic resistome and host-tracking in drinking water deciphered by a large scale survey. Microbiome 2017, 5, 154. [CrossRef]

10. Wright, G.D. The antibiotic resistome: The nexus of chemical and genetic diversity. Nat. Rev. Microbiol. 2007, 5, 175-186. [CrossRef]

11. Chen, Y.; Chen, H.; Zhang, L.; Jiang, Y.; Gin, K.Y.H.; He, Y. Occurrence, distribution, and risk assessment of antibiotics in a subtropical river-reservoir system. Water 2018, 10, 104. [CrossRef]

12. Pruden, A.; Larsson, D.G.J.; Amézquita, A.; Collignon, P.; Brandt, K.K.; Graham, D.W.; Lazorchak, J.M.; Suzuki, S.; Silley, P.; Snape, J.R.; et al. Management of Options for Reducing the Release of Antibiotics. Environ. Health Perspect. 2013, 121, 878-885. [CrossRef] [PubMed]

13. Berglund, B. Environmental dissemination of antibiotic resistance genes and correlation to anthropogenic contamination with antibiotics. Infect. Ecol. Epidemiol. 2015, 5, 28564. [CrossRef] [PubMed]

14. Szymańska, U.; Wiergowski, M.; Sołtyszewski, I.; Kuzemko, J.; Wiergowska, G.; Woźniak, M.K. Presence of antibiotics in the aquatic environment in Europe and their analytical monitoring: Recent trends and perspectives. Microchem. J. 2019, 147, 729-740. [CrossRef]

15. Casanova, L.M.; Sobsey, M.D. Antibiotic-resistant enteric bacteria in environmental waters. Water 2016, 8, 561. [CrossRef]

16. Kubera, Ł.; Malecka-Adamowicz, M.; Jankowiak, E.; Dembowska, E.; Perliński, P.; Hejze, K. Influence of environmental and anthropogenic factors on microbial ecology and sanitary threat in the final stretch of the Brda River. Water 2019, 11, 922. [CrossRef]

17. Thakali, O.; Tandukar, S.; Brooks, J.P.; Sherchan, S.P.; Sherchand, J.B.; Haramoto, E. The occurrence of antibiotic resistance genes in an Urban River in Nepal. Water 2020, 12, 450. [CrossRef]

18. Xu, L.; Ouyang, W.; Qian, Y.; Su, C.; Su, J.; Chen, H. High-throughput profiling of antibiotic resistance genes in drinking water treatment plants and distribution systems. Environ. Pollut. 2016, 213, 119-126. [CrossRef] [PubMed]

19. Bai, X.; Ma, X.; Xu, F.; Li, J.; Zhang, H.; Xiao, X. The drinking water treatment process as a potential source of affecting the bacterial antibiotic resistance. Sci. Total Environ. 2015, 533, 24-31. [CrossRef]

20. Chao, Y.; Ma, L.; Yang, Y.; Ju, F.; Zhang, X.X.; Wu, W.M.; Zhang, T. Metagenomic analysis reveals significant changes of microbial compositions and protective functions during drinking water treatment. Sci. Rep. 2013, 3, 3550. [CrossRef]

21. Guo, X.; Li, J.; Yang, F.; Yang, J.; Yin, D. Prevalence of sulfonamide and tetracycline resistance genes in drinking water treatment plants in the Yangtze River Delta, China. Sci. Total Environ. 2014, 493, 626-631. [CrossRef]

22. Zheng, J.; Chen, T.; Chen, H. Antibiotic resistome promotion in drinking water during biological activated carbon treatment: Is it influenced by quorum sensing? Sci. Total Environ. 2018, 612, 1-8. [CrossRef] [PubMed]

23. Ferro, G.; Guarino, F.; Cicatelli, A.; Rizzo, L. $\beta$-lactams resistance gene quantification in an antibiotic resistant Escherichia coli water suspension treated by advanced oxidation with $\mathrm{UV} / \mathrm{H}_{2} \mathrm{O}_{2}$. J. Hazard. Mater. 2017, 323, 426-433. [CrossRef] [PubMed]

24. Furukawa, T.; Jikumaru, A.; Ueno, T.; Sei, K. Inactivation effect of antibiotic-resistant gene using chlorine disinfection. Water 2017, 9, 547. [CrossRef]

25. Hao, H.; Shi, D.-Y.; Yang, D.; Yang, Z.-W.; Qiu, Z.-G.; Liu, W.-L.; Shen, Z.-Q.; Yin, J.; Wang, H.-R.; Li, J.-W.; et al. Profiling of intracellular and extracellular antibiotic resistance genes in tap water. J. Hazard. Mater. 2019, 365, 340-345. [CrossRef] [PubMed]

26. Jia, S.; Shi, P.; Hu, Q.; Li, B.; Zhang, T.; Zhang, X.X. Bacterial Community Shift Drives Antibiotic Resistance Promotion during Drinking Water Chlorination. Environ. Sci. Technol. 2015, 49, 12271-12279. [CrossRef] 
27. Lin, W.; Zhang, M.; Zhang, S.; Yu, X. Can chlorination co-select antibiotic-resistance genes? Chemosphere 2016, 156, 412-419. [CrossRef]

28. Liu, S.S.; Qu, H.M.; Yang, D.; Hu, H.; Liu, W.L.; Qiu, Z.G.; Hou, A.M.; Guo, J.; Li, J.W.; Shen, Z.Q.; et al. Chlorine disinfection increases both intracellular and extracellular antibiotic resistance genes in a full-scale wastewater treatment plant. Water Res. 2018, 136, 131-136. [CrossRef]

29. Lu, J.; Tian, Z.; Yu, J.; Yang, M.; Zhang, Y. Distribution and abundance of antibiotic resistance genes in sand settling reservoirs and drinking water treatment plants across the Yellow River, China. Water 2018, 10, 246. [CrossRef]

30. Shi, P.; Jia, S.; Zhang, X.-X.; Zhang, T.; Cheng, S.; Li, A. Metagenomic insights into chlorination effects on microbial antibiotic resistance in drinking water. Water Res. 2013, 47, 111-120. [CrossRef]

31. Su, H.C.; Liu, Y.S.; Pan, C.G.; Chen, J.; He, L.Y.; Ying, G.G. Persistence of antibiotic resistance genes and bacterial community changes in drinking water treatment system: From drinking water source to tap water. Sci. Total Environ. 2018, 616-617, 453-461. [CrossRef]

32. Xi, C.; Zhang, Y.; Marrs, C.F.; Ye, W.; Simon, C.; Foxman, B.; Nriagu, J. Prevalence of antibiotic resistance in drinking water treatment and distribution systems. Appl. Environ. Microbiol. 2009, 75, 5714-5718. [CrossRef] [PubMed]

33. McCoy, S.T.; Vanbriesen, J.M. Temporal variability of bacterial diversity in a chlorinated drinking water distribution system. J. Environ. Eng. 2012, 138, 786-795. [CrossRef]

34. Vaz-Moreira, I.; Egas, C.; Nunes, O.C.; Manaia, C.M. Bacterial diversity from the source to the tap: A comparative study based on $16 \mathrm{~S}$ rRNA gene-DGGE and culture-dependent methods. FEMS Microbiol. Ecol. 2013, 83, 361-374. [CrossRef] [PubMed]

35. Edberg, S.C.; Allen, M.J. Virulence and risk from drinking water of heterotrophic plate count bacteria in human population groups. Int. J. Food Microbiol. 2004, 92, 255-263. [CrossRef] [PubMed]

36. Seidman, J.C.; Anitha, K.P.; Kanungo, R.; Bourgeois, A.L.; Coles, C.L. Risk factors for antibiotic-resistant E. coli in children in a rural area. Epidemiol. Infect. 2009, 137, 879-888. [CrossRef]

37. Coleman, B.L.; Salvadori, M.I.; McGeer, A.J.; Sibley, K.A.; Neumann, N.F.; Bondy, S.J.; Gutmanis, I.A.; McEwn, S.A.; Lavoie, M.; Strong, D.; et al. The role of drinking water in the transmission of antimicrobial-resistant E. coli. Epidemiol. Infect. 2012, 140, 633-642. [CrossRef]

38. Salyers, A.A.; Gupta, A.; Wang, Y. Human intestinal bacteria as reservoirs for antibiotic resistance genes. Trends Microbiol. 2004, 12, 412-416. [CrossRef]

39. Armstrong, J.L.; Calomiris, J.J.; Seidler, R.J. Selection of antibiotic-resistant standard plate count bacteria during water treatment. Appl. Environ. Microbiol. 1982, 44, 308-316. [CrossRef]

40. Armstrong, J.L.; Shigeno, D.S.; Calomiris, J.J.; Seidler, R.J. Antibiotic-resistant bacteria in drinking water. Appl. Environ. Microbiol. 1981, 42, 277-283. Available online: https://www.ncbi.nlm.nih.gov/pmc/articles/ PMC244002/ (accessed on 1 July 2020).

41. Bergeron, S.; Boopathy, R.; Nathaniel, R.; Corbin, A.; LaFleur, G. Presence of antibiotic resistant bacteria and antibiotic resistance genes in raw source water and treated drinking water. Int. Biodeterior. Biodegrad. 2015, 102, 370-374. [CrossRef]

42. Faria, C.; Vaz-Moreira, I.; Serapicos, E.; Nunes, O.C.; Manaia, C.M. Antibiotic resistance in coagulase negative staphylococci isolated from wastewater and drinking water. Sci. Total Environ. 2009, 407, 3876-3882. [CrossRef]

43. Figueira, V.; Serra, E.A.; Vaz-Moreira, I.; Brandão, T.R.S.; Manaia, C.M. Comparison of ubiquitous antibiotic-resistant Enterobacteriaceae populations isolated from wastewaters, surface waters and drinking waters. J. Water Health 2012, 10, 1-10. [CrossRef] [PubMed]

44. Figueira, V.; Vaz-Moreira, I.; Silva, M.; Manaia, C.M. Diversity and antibiotic resistance of Aeromonas spp. in drinking and waste water treatment plants. Water Res. 2011, 45, 5599-5611. [CrossRef] [PubMed]

45. Flores Ribeiro, A.; Bodilis, J.; Alonso, L.; Buquet, S.; Feuilloley, M.; Dupont, J.P.; Pawlak, B. Occurrence of multi-antibiotic resistant Pseudomonas spp. in drinking water produced from karstic hydrosystems. Sci. Total Environ. 2014, 490, 370-378. [CrossRef] [PubMed]

46. Khan, S.; Beattie, T.K.; Knapp, C.W. Relationship between antibiotic- and disinfectant-resistance profiles in bacteria harvested from tap water. Chemosphere 2016, 152, 132-141. [CrossRef]

47. Khan, S.; Knapp, C.W.; Beattie, T.K. Antibiotic resistant bacteria found in municipal drinking water. Environ. Process. 2016, 3, 541-552. [CrossRef] 
48. Leginowicz, M.; Siedlecka, A.; Piekarska, K. Biodiversity and antibiotic resistance of bacteria isolated from tap water in Wrocław, Poland. Environ. Prot. Eng. 2018, 44, 85-98. [CrossRef]

49. Narciso-da-Rocha, C.; Vaz-Moreira, I.; Manaia, C.M. Genotypic diversity and antibiotic resistance in Sphingomonadaceae isolated from hospital tap water. Sci. Total Environ. 2014, 466-467, 127-135. [CrossRef]

50. Narciso-Da-Rocha, C.; Vaz-Moreira, I.; Svensson-Stadler, L.; Moore, E.R.B.; Manaia, C.M. Diversity and antibiotic resistance of Acinetobacter spp. in water from the source to the tap. Appl. Microbiol. Biotechnol. 2013, 97, 329-340. [CrossRef]

51. Rocha, J.; Fernandes, T.; Riquelme, M.V.; Zhu, N.; Pruden, A.; Manaia, C.M. Comparison of culture-and quantitative PCR-based indicators of antibiotic resistance in wastewater, recycled water, and tap water. Int. J. Environ. Res. Public Health 2019, 16, 4217. [CrossRef]

52. Schwartz, T.; Kohnen, W.; Jansen, B.; Obst, U. Detection of antibiotic-resistant bacteria and their resistance genes in wastewater, surface water, and drinking water biofilms. FEMS Microbiol. Ecol. 2003, 43, 325-335. [CrossRef]

53. Siedlecka, A.; Piekarska, K. Application of NGS for studying the antibiotic resistant microbiome in Wrocław tap water. In Proceedings of the 10th Conference on Interdisciplinary Problems in Environmental Protection and Engineering EKO-DOK 2018, E3S Web of Conferences, 44(00161), Polanica-Zdrój, Poland, 16-18 April 2018. [CrossRef]

54. Siedlecka, A.; Piekarska, K. Antibiotic resistance in tap water during the summer season-Preliminary research. In Proceedings of the Nternational Conference on Advances in Energy Systems and Environmental Engineering ( $\beta 19)$, E3S Web of Conferences, 116(00077), Wrocław, Poland, 9-12 June 2019. [CrossRef]

55. Siedlecka, A.; Wolf-Baca, M.; Piekarska, K. Seasonal variability of antibiotic resistance and biodiversity of tap water bacteria in Wrocław, Poland. Environ. Prot. Eng. 2020, 46, 93-109. [CrossRef]

56. Subba, P.; Joshi, D.R.; Bhatta, D.R. Antibiotic resistance pattern and plasmid profiling of thermotolerant Escherichia coli isolates in drinking water. J. Nepal Health Res. Counc. 2013, 11, 44-48. [PubMed]

57. Talukdar, P.K.; Rahman, M.; Rahman, M.; Nabi, A.; Islam, Z.; Hoque, M.M.; Endtz, H.P.; Islam, M.A. Antimicrobial Resistance, Virulence Factors and Genetic Diversity of Escherichia coli Isolates from Household Water Supply in Dhaka, Bangladesh. PLoS ONE 2013, 8, e61090. [CrossRef] [PubMed]

58. Vaz-Moreira, I.; Nunes, O.C.; Manaia, C.M. Diversity and antibiotic resistance patterns of Sphingomonadaceae isolates from drinking water. Appl. Environ. Microbiol. 2011, 77, 5697-5706. [CrossRef]

59. Vaz-Moreira, I.; Nunes, O.C.; Manaia, C.M. Diversity and antibiotic resistance in Pseudomonas spp. from drinking water. Sci. Total Environ. 2012, 426, 366-374. [CrossRef]

60. Vaz-Moreira, I.; Nunes, O.C.; Manaia, C.M. Ubiquitous and persistent Proteobacteria and other Gram-negative bacteria in drinking water. Sci. Total Environ. 2017, 586, 1141-1149. [CrossRef]

61. European Surveillance of Antimicrobial Consumption Network (ESAC-Net). Available online: https:// www.ecdc.europa.eu/en/about-us/partnerships-and-networks/disease-and-laboratory-networks/esac-net (accessed on 1 July 2020).

62. Wolf-Baca, M.; Piekarska, K. Biodiversity of organisms inhabiting the water supply network of Wroclaw. Detection of pathogenic organisms constituting a threat for drinking water recipients. Sci. Total Environ. 2020, 715, 136732. [CrossRef]

63. Lee, S.M.; Lee, H.M.; Yoo, D.G.; Kim, J.H. A comparative study on a hydraulic and water-quality analysis method for determining rechlorination injection points for a water-supply network. Water 2019, 11, 697. [CrossRef]

64. Andrews, J.M. Determination of minimum inhibitory concentrations. J. Antimicrob. Chemother. 2002, 49, 1049. [CrossRef]

65. The European Committee on Antimicrobial Susceptibility Testing-EUCAST. Available online: https: //eucast.org/ (accessed on 1 July 2020).

66. Macrogen USA-Universal Primer List. Available online: https://www.macrogenusa.com/support/seq/ primer.jsp (accessed on 1 July 2020).

67. Muyzer, G.; de Waal, E.C.; Uitterlinden, A.G. Profiling of complex microbial populations by denaturing gradient gel electrophoresis analysis of polymerase chain reaction-amplified genes coding for 16S rRNA. Appl. Environ. Microbiol. 1993, 59, 695-700. Available online: https:/www.ncbi.nlm.nih.gov/pmc/articles/ PMC202176/ (accessed on 1 July 2020). 
68. Regulation of the Minister of Health from December 7, 2017 on the Quality of Water Intended for Human Consumption, Dz. U. 2017, 2294. Available online: http://isap.sejm.gov.pl/isap.nsf/download. xsp/WDU20170002294/O/D20172294.pdf (accessed on 1 July 2020). (In Polish)

69. Pruden, A.; Arabi, M.; Storteboom, H.N. Correlation between upstream human activities and riverine antibiotic resistance genes. Environ. Sci. Technol. 2012, 46, 11541-11549. [CrossRef]

70. Leung, H.W.; Jin, L.; Wei, S.; Tsui, M.M.P.; Zhou, B.; Jiao, L.; Cheung, P.C.; Chun, Y.K.; Murphy, M.B.; Lam, P.K.S. Pharmaceuticals in tap water: Human health risk assessment and proposed monitoring framework in China. Environ. Health Perspect. 2013, 121, 839-846. [CrossRef] [PubMed]

71. Wang, H.; Wang, N.; Wang, B.; Zhao, Q.; Fang, H.; Fu, C.; Tang, C.; Jiang, F.; Zhou, Y.; Chen, Y.; et al. Antibiotics in Drinking Water in Shanghai and Their Contribution to Antibiotic Exposure of School Children. Environ. Sci. Technol. 2016, 50, 2692-2699. [CrossRef] [PubMed]

72. Yiruhan; Wang, Q.J.; Mo, C.H.; Li, Y.W.; Gao, P.; Tai, Y.P.; Zhang, Y.; Ruan, Z.L.; Xu, J.W. Determination of four fluoroquinolone antibiotics in tap water in Guangzhou and Macao. Environ. Pollut. 2010, 158, 2350-2358. [CrossRef]

73. Segura, P.A.; François, M.; Gagnon, C.; Sauvé, S. Review of the occurrence of anti-infectives in contaminated wastewaters and natural and drinking waters. Environ. Health Perspect. 2009, 117, 675-684. [CrossRef] [PubMed]

74. Lv, L.; Jiang, T.; Zhang, S.; Yu, X. Exposure to mutagenic disinfection byproducts leads to increase of antibiotic resistance in Pseudomonas aeruginosa. Environ. Sci. Technol. 2014, 48, 8188-8195. [CrossRef]

75. Farkas, A.; Butiuc-Keul, A.; Ciatarâş, D.; Neamţu, C.; Crăciunaş, C.; Podar, D.; Drăgan-Bularda, M. Microbiological contamination and resistance genes in biofilms occurring during the drinking water treatment process. Sci. Total Environ. 2013, 443, 932-938. [CrossRef]

76. Szekeres, E.; Chiriac, C.M.; Baricz, A.; Szőke-Nagy, T.; Lung, I.; Soran, M.L.; Rudi, K.; Dragos, N.; Coman, C. Investigating antibiotics, antibiotic resistance genes, and microbial contaminants in groundwater in relation to the proximity of urban areas. Environ. Pollut. 2018, 236, 734-744. [CrossRef]

77. Okitsu, N.; Kaieda, S.; Yano, H.; Nakano, R.; Hosaka, Y.; Okamoto, R.; Kobayashi, T.; Inoue, M. Characterization of ermB gene transposition by Tn1545 and Tn917 in macrolide-resistant Streptococcus pneumoniae isolates. J. Clin. Microbiol. 2005, 43, 168-173. [CrossRef]

78. Ibáñez de Aldecoa, A.L.; Zafra, O.; González-Pastor, J.E. Mechanisms and regulation of extracellular DNA release and its biological roles in microbial communities. Front. Microbiol. 2017, 8, 1-19. [CrossRef]

79. Mao, D.; Luo, Y.; Mathieu, J.; Wang, Q.; Feng, L.; Mu, Q.; Feng, C.; Alvarez, P.J.J. Persistence of extracellular DNA in river sediment facilitates antibiotic resistance gene propagation. Environ. Sci. Technol. 2014, 48, 71-78. [CrossRef]

80. Lorenz, M.G.; Wackernagel, W. Bacterial gene transfer by natural genetic transformation in the environment. Microbiol. Rev. 1994, 58, 563-602. Available online: https://www.ncbi.nlm.nih.gov/pmc/articles/PMC372978/ (accessed on 1 July 2020).

81. Davis, M.A.; Besser, T.E.; Orfe, L.H.; Baker, K.N.K.; Lanier, A.S.; Broschat, S.L.; New, D.; Call, D.R. Genotypic-phenotypic discrepancies between antibiotic resistance characteristics of Escherichia coli isolates from calves in management settings with high and low antibiotic use. Appl. Environ. Microbiol. 2011, 77, 3293-3299. [CrossRef] [PubMed]

82. Hou, L.; Zhou, Q.; Wu, Q.; Gu, Q.; Sun, M.; Zhang, J. Spatiotemporal changes in bacterial community and microbial activity in a full-scale drinking water treatment plant. Sci. Total Environ. 2018, 625, 449-459. [CrossRef] [PubMed]

83. Nescerecka, A.; Juhna, T.; Hammes, F. Identifying the underlying causes of biological instability in a full-scale drinking water supply system. Water Res. 2018, 135, 11-21. [CrossRef] [PubMed]

84. Perrin, Y.; Bouchon, D.; Delafont, V.; Moulin, L.; Héchard, Y. Microbiome of drinking water: A full-scale spatio-temporal study to monitor water quality in the Paris distribution system. Water Res. 2019, 149, 375-385. [CrossRef]

85. Shrivastava, R.; Upreti, R.K.; Jain, S.R.; Prasad, K.N.; Seth, P.K.; Chaturvedi, U.C. Suboptimal chlorine treatment of drinking water leads to selection of multidrug-resistant Pseudomonas aeruginosa. Ecotoxicol. Environ. Saf. 2004, 58, 277-283. [CrossRef] 
86. Asghari, F.B.; Pakdel, M.; Mohammadi, A.A.; Yousefi, M. Spatial and temporal variation of physicochemical and microbial quality of drinking water for the distribution network in Maku, Iran. Desalin. Water Treat. 2019, 142, 82-89. [CrossRef]

87. Henne, K.; Kahlisch, L.; Höfle, M.G.; Brettar, I. Seasonal dynamics of bacterial community structure and composition in cold and hot drinking water derived from surface water reservoirs. Water Res. 2013, 47, 5614-5630. [CrossRef]

88. Girolamini, L.; Lizzadro, J.; Mazzotta, M.; Iervolino, M.; Dormi, A.; Cristino, S. Different trends in microbial contamination between two types of microfiltered water dispensers: From risk analysis to consumer health preservation. Int. J. Environ. Res. Public Health 2019, 16, 272. [CrossRef]

89. Zhang, J.; Li, W.; Chen, J.; Wang, F.; Qi, W.; Li, Y. Impact of disinfectant on bacterial antibiotic resistance transfer between biofilm and tap water in a simulated distribution network. Environ. Pollut. 2019, 246, 131-140. [CrossRef]

(C) 2020 by the authors. Licensee MDPI, Basel, Switzerland. This article is an open access article distributed under the terms and conditions of the Creative Commons Attribution (CC BY) license (http://creativecommons.org/licenses/by/4.0/). 